\title{
Transient expression of foreign DNA during embryonic and larval development of the medaka fish (Oryzias latipes)*
}

\author{
Christoph Winkler $^{1}$, Jürgen R. Vielkind ${ }^{2}$ and Manfred Schart ${ }^{1}$ \\ ${ }^{1}$ Genzentrum, Max-Planck-Institut für Biochemie, W-8033 Martinsried, FRG \\ ${ }^{2}$ British Columbia Cancer Research Centre, Vancouver, British Columbia, Canada \\ Received August 28, 1990 / November 7, 1990
}

\begin{abstract}
Summary. Species of small fish are becoming useful tools for studies on vertebrate development. We have investigated the developing embryo of the Japanese medaka for its application as a transient expression system for the in vivo analysis of gene regulation and function. The temporal and spatial expression patterns of bacterial chloramphenicol acetyltransferase and galactosidase reporter genes injected in supercoiled plasmid form into the cytoplasm of one cell of the two-cell stage embryo was promoter-specific. The transient expression was found to be mosaic within the tissue and organs reflecting the unequal distribution of extrachromosomal foreign DNA and the intensive cell mixing movements that occur in fish embryogenesis. The expression data are consistent with data on DNA fate. Foreign DNA persisted during embryogenesis and was still detectable in some 3- and 9-month-old adult fish; it was found in high molecular weight form as well as in circular plasmid conformations. The DNA was replicated during early and late embryogenesis. Our data indicate that the developing medaka embryo is a powerful in vivo assay system for studies of gene regulation and function.
\end{abstract}

Key words: Medaka - Gene transfer - Transient expression - DNA fate - Fish developmental biology

\section{Introduction}

A central problem in developmental biology is how expression of those genes which are instrumental in the development of an organism is regulated. Fish have proven to be advantageous in the study of developmental processes (for a review see Powers 1989): most species produce an abundance of eggs which are of relatively large size, embryogenesis proceeds quickly through morphologically distinct and clearly defined stages and, because of the transparency of the embryo, development

Offprint requests to: $\mathrm{M}$. Schart

* This work contains part of the $\mathrm{PhD}$ thesis of $\mathrm{C}$. Winkler can be observed relatively easy allowing, for example, cell lineage studies (Streisinger et al. 1981; Kimmel and Warga 1988). In addition, fish offer the possibility of combining genetic and molecular approaches for the study of developmental processes in vertebrates in general, similar to successful strategies that have elucidated the mechanisms of early embryogenesis in Drosophila. This has recently led to the isolation and structural characterisation of homeotic genes (Eiken et al. 1987; Fjose et al. 1988; Njolstad et al. 1990), growth hormone genes (Sekine et al. 1985; Agellon and Chen 1986; GonzalesVillasenor et al. 1988) and metallothionein genes (Bonham et al. 1987) in fish. Another aspect of the molecular basis of fish embryogenesis is the function and regulation of potentially oncogenic genes which are assumed to regulate normal developmental processes (Wittbrodt et al. 1989; Vielkind et al. 1989; Schartl et al. 1991). Several such proto-oncogenes have been isolated (Nemoto et al. 1986; Van Beneden et al. 1986; Hannig et al. 1991) and a large number of potentially important developmental genes of all kinds may be expected in the near future.

For functional analysis of regulatory regions of developmental genes, an in vivo system rather than an in vitro assay is required. Generally, for such analyses, stable transgenic animals have been produced in Caenorhabditis elegans (Fire 1986), sea urchins (Flytzanis et al. 1985), Drosophila (Rubin and Spradling 1982), Xenopus (Etkin et al. 1984), mouse (Palmiter and Brinster 1986; Jaenisch 1988), and recently in fish (for a review see Maclean et al. 1987; Stuart et al. 1988; Guyomard et al. 1989). However, stable transgenic systems have several limitations: (1) production of stable transgenic lines is time consuming and therefore only a limited number of regulatory sequences can be tested; (2) integration site and integrated copy number can obscure the true characteristics of such sequences; and (3) genomic imprinting, as reported in the mouse (Surani et al. 1988), may additionally alter the expression of the transgene.

Transient expression systems, on the other hand, may not be affected by these disadvantages. Therefore, they represent alternative test systems and have been success- 
fully employed in gene regulation and gene function studies in Drosophila (Steller and Pirrotta 1984; Martin et al. 1986) and sea urchins (McMahon et al. 1985). In Drosophila it was shown that the introduced DNA is expressed in a temporally and tissue-specific manner (Steller and Pirrotta 1984; Martin et al. 1986). In vertebrates, Xenopus oocytes and embryos have been used as transient expression systems. However, expression of foreign DNA was only examined in early embryogenesis at the midblastula stage (Etkin and Balcells 1985) or up to early tailbud stage (Krone and Heikkila 1989).

In fish there has so far been only one single report, showing that foreign DNA microinjected into the fertilized egg of the medaka fish can be transiently expressed during development (Chong and Vielkind 1989). This and earlier attempts to use the medaka for production of stable transgenic fish (Ozato et al. 1986, 1989) suggested that this organism might be a suitable experimental system for gene transfer experiments, because it was shown that the medaka embryo is easier to micromanipulate and to inject, and tolerates a wider concentration range of injected foreign DNA than other species commonly used for fish developmental biology, e.g. the zebrafish (Stuart et al. 1988; Vielkind et al. 1990).

In this report we have microinjected the chloramphenicol acetyltransferase (CAT) and the lac $Z$ genes as reporter genes driven by various heterologous and homologous transcriptional control regions into fertilized eggs of the Japanese medaka. We document that this system can be used as an in vivo system for the analysis of sequences regulating gene expression during ontogenesis.

\section{Materials and methods}

Egg collection and embryo culture. Oryzias latipes (Teleostei: Cyprinodontidae) were purchased from Carolina Biological Supply Company (Burlington, North Carolina, USA). Adult fish were maintained under standard conditions (Kirchen and West 1976) with an artificial photoperiod of $10 \mathrm{~h}$ darkness to $14 \mathrm{~h}$ light to induce reproductive activities. Clusters of fertilized eggs were collected 1-2 $\mathrm{h}$ after the onset of light and kept in Yamamoto Ringer saline $(0.75 \% \mathrm{NaCl}, 0.02 \% \mathrm{KCl}, 0.02 \%$ $\mathrm{CaCl}_{2} \mathrm{pH} 7.3$; Yamamoto 1961) prior to injection. Injected medaka embryos were reared in a medium containing $0.1 \% \mathrm{NaCl}, 0.003 \% \mathrm{KCl}, 0.004 \% \mathrm{CaCl}_{2} \cdot 2 \mathrm{H}_{2} \mathrm{O}$, $0.016 \% \mathrm{MgSO}_{4} \cdot 7 \mathrm{H}_{2} \mathrm{O}, 0.0001 \%$ methylene blue (Rugh 1962) and transferred to aquarium water immediately after hatching.

Reporter gene constructs. All constructs were tested for fidelity of expression in vitro prior to the embryo injection experiments (data not shown).

1. Chloramphenicol acetyltransferase (CAT) plasmids. pCMVTkCAT (Altschmied, Schulz and Renkawitz, unpublished). A $700 \mathrm{bp} A l u I$ fragment containing the human cytomegalovirus enhancer (CMV) was cloned in front of the thymidine kinase (Tk) promoter from herpes simplex virus, fused to a CAT gene which was followed by the simian virus 40 (SV40) polyadenylation signal. The Tk-CAT transcription unit is contained within pBLCAT2.

phMTIIA-CAT (Friedenreich and Schartl 1990) was constructed by cloning the 835 bp human metallothionein IIA (hMT $\mathrm{hIA}_{\text {) }}$ HindIII-Ncol promoter fragment from p84H (Karin and Richards 1982) in front of the CAT gene of $\mathrm{pBLCAT} 2$, after excision of the Tk promoter.

pX47CAT (Friedenreich and Schartl 1990) contains 830 bp of a promoter (X47) from the platyfish Xiphophorus maculatus in front of the CAT gene. The promoter shows some similarity to the consensus sequence for metal responsive elements (Karin and Richards 1982) and contains TATA, CAAT and SP1-like sequence motives. Plasmids were originally constructed by cloning the $830 \mathrm{bp} \mathrm{EcoRI-HindIII}$ fragment of X47 into the $5^{\prime}$ polylinker of pBLCAT2, after excision of the Tk promoter.

pBLCAT2 (Luckow and Schütz 1987) contains the Tk promoter from herpes simplex virus in front of the CAT gene.

pBLCAT3 (Luckow and Schütz 1987) contains the CAT gene without any functional promoter sequences.

2. $\beta$-Galactosidase (lacZ) constructs. pSV40/2lacZ (B. Schmidt and J.R. Vielkind, unpublished) contains the SV40 ori/early promoter region in front of the lacZ gene. The contruct is a modified pCH110 plasmid (Pharmacia), due to an additional SV40 polyadenylation signal.

pRSVlacZ (Altschmied, Schulz and Renkawitz, unpublished) contains the $600 \mathrm{bp}$ HindIII-NdeI fragment of the Rous sarcoma virus long-terminal repeat (RSVLTR) (Gorman et al. 1982a) in front of the lacZ gene and the SV40 polyadenylation site.

Preparation of plasmid DNA. Plasmid DNA was extracted according to a modified boiling method (Holmes and Quigley 1981). Lysis was performed in STET (8\% sucrose, $0.5 \%$ Triton $\mathrm{X}-100,50 \mathrm{mM}$ TRIS- $\mathrm{HCl} \mathrm{pH} 8.0$, $50 \mathrm{mM}$ EDTA) and $10 \mathrm{mg} / \mathrm{ml}$ lysozyme by boiling for $1 \mathrm{~min}$. After high speed centrifugation and phenol-chloroform extraction, the crude nucleic acids were precipitated with isopropanol and subjected to an ethidium bromide-CsCl centrifugation step. Plasmid DNA was obtained after purification by two successive CsCl-ethidium bromide equilibrium density centrifugations.

Microinjection. Microinjection was performed essentially as described (Chong and Vielkind 1989). Approximately $500 \mathrm{pl}$ (equivalent to $25 \mathrm{pg}$ ) of supercoiled plasmid DNA were microinjected into the cytoplasm of one cell of a two-cell stage medaka embryo. DNA was dissolved to a final concentration of $50 \mu \mathrm{g} / \mathrm{ml}$ in Yamamoto Ringer saline containing $0.1 \%$ phenol red, to follow the injected solution. Injections were done under a Zeiss stereomicroscope under a magnification range of $30-50 \times$ using glass capillary needles $(3-5 \mu \mathrm{m}$ in diameter) mounted on a micro-manipulator (Leitz). Constant pressure for injection was provided by an Eppendorf micro-injector. During injection embryos were held in egg-size wells of 
a $1.5 \%$ agarose bottom submerged in Yamamoto Ringer saline (Yamamoto 1961).

Preparation of genomic DNA. Three embryos per examined stage were pooled and DNA was extracted according to the method described by Olson et al. (1979). Samples were homogenized in $150 \mu \mathrm{l}$ buffer containing $1 \mathrm{M}$ sorbitol, $0.01 \mathrm{M}$ EDTA and $0.1 \mathrm{M}$ sodium citrate $\mathrm{pH}$ 5.8. After addition of $350 \mu \mathrm{l}$ buffer containing $3 \%$ Sarkosyl and $0.5 \mathrm{M}$ TRIS pH 9.0, lysis was performed at $65^{\circ} \mathrm{C}$ for $15 \mathrm{~min}$. DNA from untreated medaka $(0.5 \mu \mathrm{g} / \mathrm{sample})$ was added as carrier. Following phenolchloroform extraction, the DNA was precipitated with $0.8 \mathrm{vol}$ of isopropanol. Half of each DNA sample was digested with a restriction enzyme that cuts the plasmid only once; the other half was analyzed undigested.

For slot-blot analysis, DNA was extracted from three different parts of the body (anterior: head; central: liver and heart; posterior: muscle of trunk region) of 2- to 3 -month-old fish. Tissues were homogenized in $20 \mathrm{mM}$ EDTA, $50 \mathrm{mM}$ TRIS $\mathrm{HCl}$ pH 7.8, $100 \mathrm{mM} \mathrm{NaCl}, 1 \%$ $\mathrm{SDS}, 0.2 \mathrm{mg}$ proteinase $\mathrm{K}$ and lysed for $2 \mathrm{~h}$ at $37^{\circ} \mathrm{C}$. The DNA was purified by phenol-chloroform and isopropanol-butanol $(3: 7)$ extractions.

Southern blotting and hybridization. After staining with ethidium bromide, the gels were treated for $20 \mathrm{~min}$ with $0.25 \mathrm{M} \mathrm{HCl}$. DNA was transferred to nylon membranes (Genescreen plus, Du Pont, or Hybond $\mathrm{N}^{+}$, Amersham) using the alkaline transfer method (Reed and Mann 1985). A $1.3 \mathrm{~kb}$ fragment containing part of the CAT gene and the SV40 polyadenylation signal was labelled with Klenow polymerase by extension of random hexamer primers (Feinberg and Vogelstein 1983).

Filters were hybridized in $50 \%$ deionized formamide, $0.1 \mathrm{mg} / \mathrm{ml}$ calf thymus DNA, $0.1 \%$ sodium pyrophosphate, $50 \mathrm{mM}$ TRIS $\mathrm{HCl} \mathrm{pH} 7.5,5 \times \mathrm{SSC}, 1 \% \mathrm{SDS}$ and $5 \times$ Denhardt's solution at $42^{\circ} \mathrm{C}$ for at least $24 \mathrm{~h}$ (approx. $1.5 \times 10^{7} \mathrm{cpm}$ per filter). Filters were washed up to two times in $0.1 \times \mathrm{SSC} / 1 \% \mathrm{SDS}$ at $68^{\circ} \mathrm{C}$.

Slot-blot analysis. DNA was denatured by incubation in $0.3 \mathrm{M} \mathrm{NaOH}$ at $65^{\circ} \mathrm{C}$ for $1 \mathrm{~h}$. After cooling to room temperature the samples were neutralized with $1 \mathrm{vol}$ of $2 \mathrm{M}$ ammonium acetate $\mathrm{pH} 7.0$, and applied in a Minifold blotting apparatus (Schleicher and Schüll) onto a Nytran membrane (Schleicher and Schüll). Slots were washed with $1 \mathrm{M}$ ammonium acetate. Hybridization with the probe described above was done in $3 \times \mathrm{SSC}$, $10 \mathrm{mM}$ TRIS $\mathrm{HCl} \mathrm{pH} 7.5,10 \mathrm{mM}$ EDTA, 0.5\% SDS, $1 \times$ Denhardt's solution and $0.1 \mathrm{mg} / \mathrm{ml}$ yeast tRNA at $68^{\circ} \mathrm{C}$ for $12 \mathrm{~h}$. Filters were washed in $0.1 \times \mathrm{SSC} / 0.1 \%$ $\operatorname{SDS}$ at $60^{\circ} \mathrm{C}$.

CAT assay. Single embryos or hatchlings were homogenized in $250 \mathrm{mM}$ TRIS $\mathrm{HCl} \mathrm{pH} \mathrm{7.8,} \mathrm{and} \mathrm{subjected} \mathrm{to}$ three cycles of freeze-thawing. The protein extract was obtained after centrifugation at $4^{\circ} \mathrm{C}$ and incubated for $2.5 \mathrm{~h}$ at $37^{\circ} \mathrm{C}$ with $2 \mu \mathrm{l}{ }^{14} \mathrm{C}$-labelled chloramphenicol (Amersham; $54 \mathrm{mCi} / \mathrm{mmol}, 200 \mu \mathrm{Ci} / \mathrm{ml}$ ) and $20 \mu \mathrm{l}$ of an aqueous acetyl coenzyme A solution $(3.4 \mathrm{mg} / \mathrm{ml}$ ) (Gor- man et al. 1982b). After extraction with ethylacetate, the reaction products were dried down in a speed-vac, redissolved in ethyl acetate and spotted on TLC plates (Polygram, Macherey-Nagel, Düren). The reaction products were separated by TLC in a chloroform-methanol mixture $(95: 5)$ for $50 \mathrm{~min}$. The plates were air-dried and scanned in a TLC linear analyzer (Berthold, Wildbad) to determine CAT conversion values. Under these conditions, CAT conversion values of up to $98 \%$ were obtained using undiluted extracts. Due to the known fact that values above $70 \%$ are not linear with respect to substrate conversion, such conversion rates might be indicative of even higher CAT expression.

5-Bromo-4-chloro-3-indolyl $\beta$-D-galactopyranoside ( $X$ Gal) staining. Embryos were fixed for $30 \mathrm{~min}$ at $4^{\circ} \mathrm{C}$ in $1 \%$ paraformaldehyde, $0.2 \%$ glutaraldehyde and $0.02 \%$ Nonidet P40 in PBS. After washing in buffer containing $10 \mathrm{mM}$ sodium phosphate, $150 \mathrm{mM} \mathrm{NaCl}$ and $1 \mathrm{mM} \mathrm{MgCl} 2$ the chorion and yolk sac were removed with fine forceps. Embryos were stained for at least $2 \mathrm{~h}$ at $37^{\circ} \mathrm{C}$ in a solution containing $10 \% \mathrm{DMSO}, 5 \mathrm{mM}$ $\mathrm{K}_{4}\left[\mathrm{Fe}(\mathrm{CN})_{6}\right], 5 \mathrm{mM} \mathrm{K}_{3}\left[\mathrm{Fe}(\mathrm{CN})_{6}\right]$ in washing buffer (see above).

\section{Results}

\section{Fate of injected DNA}

In total, 3000 embryos have been injected with different constructs for the determination of the fate of DNA and expression studies. The survival rate of the injected embryos 2 weeks after injection (at hatching stage) was $70 \%$ compared to $78 \%$ of non-injected control embryos.

To follow the fate of the injected DNA, pCMVTKCAT plasmid DNA was injected into the embryos and analyzed by Southern blot hybridization (Fig. 1). Circular plasmid DNA was used because it has been shown in mammals in vitro (Weintraub et al. 1986) as well as in Xenopus oocytes (Harland et al. 1983), that higher expression of the introduced DNA is obtained if transfected in circular rather than in linearized form. Similarly, there are indications that this is also true in fish (Chong and Vielkind 1989; J.R. Vielkind, unpublished data). The different conformational forms and the relative amounts of these were confirmed in independent experiments using topoisomerase I-treated DNA from the injected embryos (data not shown). The DNA preparation prior to injection consisted predominantly of plasmid in supercoiled (RF I) and relaxed (nicked open circular, RF II) form with minor amounts of plasmid multimers. Immediately after injection $(0 \mathrm{~min})$ the plasmid DNA was found to be mainly in a relaxed form (covalently closed circular, RF IV) pointing to conformational changes by shearing forces during the injection procedure. Nevertheless, RF I and RF II form plasmid DNA could be detected. As early as $1 \mathrm{~h}$ after injection, an increase in the amount of RF I and RF II form plasmid DNA was observed while RF IV decreased. Additionally, a linearized form of the injected plasmid was visible at this stage, which persisted through the 


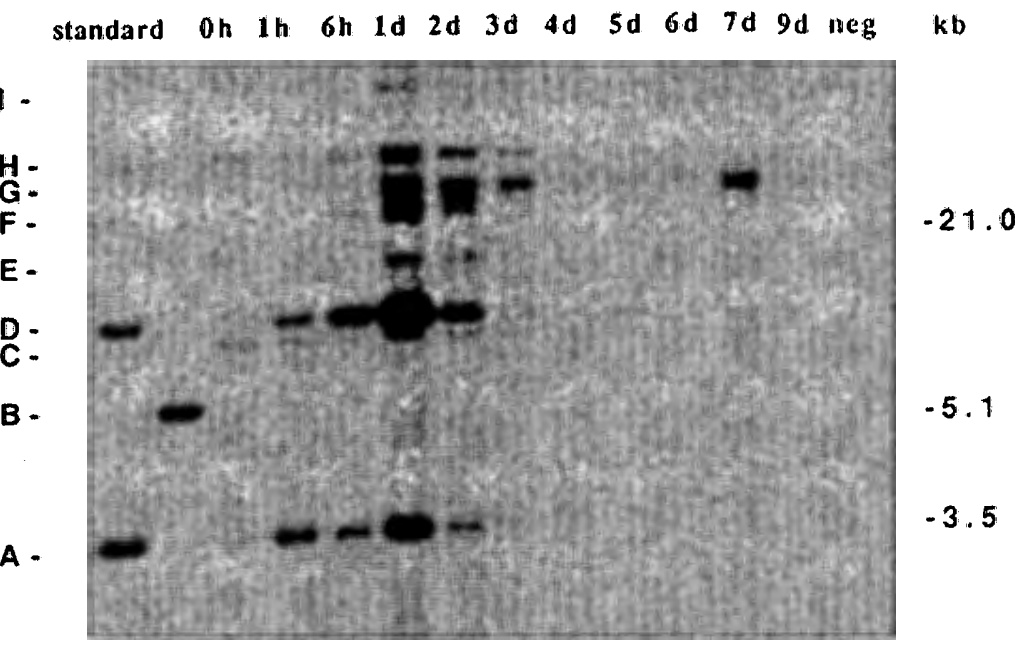

$\begin{array}{lllllllllllllll}1 & 2 & 3 & 4 & 5 & 6 & 7 & 8 & 9 & 10 & 11 & 12 & 13 & 14\end{array}$

Fig. 1. Southern blot analysis of DNA extracted from various embryonic stages derived from two-cell stage embryos injected with pCMVTkCAT plasmid DNA. $100 \mathrm{pg}$ supercoiled (lane 1), $50 \mathrm{pg}$ linearized pCMVTkCAT (lane 2) and aliquots of DNA extracted from 1.5 embryos injected with pCMVTkCAT (lanes 3-13) or from untreated adult medaka (lane 14) were electrophoresed and hybridized after blotting with a ${ }^{32} \mathrm{P}$-labelled $1.3 \mathrm{~kb}$ fragment containing part of the chloramphenicol acetyltransferase (CAT) coding sequence and the SV40 polyA signal. Each DNA sample also contained $250 \mathrm{ng}$ carrier DNA from adult, untreated medaka. DNA in lanes 3-13 was from embryos $0,1 \mathrm{~h}, 6 \mathrm{~h}, 22 \mathrm{~h}, 2-8$ days, and 9 days after plasmid DNA injection. A, plasmid in supercoiled

first 3 days of development. The total amount of pCMVTkCAT DNA increased to a maximum after approximately $24 \mathrm{~h}$, accompanied by the appearance of plasmid multimers (concatemers and concatenates). Interestingly, a hybridization signal was also observed in the fraction which comigrates with high molecular weight (hmw) DNA of the recipient. Between 2 and 6 days after injection a decrease in the different forms of pCMVTkCAT was observed. A second peak in the amount of DNA, predominantly the hmw form, was observed at day 7 . Thereafter, the amount of foreign DNA decreased again; however, we still detected a considerable amount of the donor plasmid by slot-blot analysis in DNA extracted from the anterior, central and posterior body region of 2- to 3-month-old animals (5 out of 20) (Fig. 2A). In one such specimen, from which sufficient DNA for additional Southern blotting was available, extrachromosomal pCMVTkCAT plasmid as RF I and RF II as well as barely detectable amounts of hmw comigrating signals were detected (Fig. 2B). In a 9-month-old fish (1 out of 5 tested) the foreign DNA was detected in the hmw fraction by Southern blot analysis. Restriction digestion revealed two fragments of sizes which cannot be explained as being derived from the different monomeric or multimeric plasmid forms described above. They therefore may represent junction fragments indicative of an integration event (Fig. 2C).

To determine the amount of foreign DNA exactly, parallel samples were digested with $X b a I$ for which there conformation (RF I); B, linearized (RF III); C, covalently closed circular (RF IV); D, nicked open circular (RF II); E, linear plasmid dimer (concatemer); F, two non-covalently linked plasmid circles (concatenate); $\mathrm{G}$, high molecular weight fraction; $\mathrm{H}$, I, large plasmid multimers. Time points represent the following embryonic stages: $0 \mathrm{~h}$, two-cell stage (time of injection); $1 \mathrm{~h}$, four-cell stage; $6 \mathrm{~h}$, late high blastula; $12 \mathrm{~h}$, early gastrula; 1 day, early neurula; 2 days, early organogenesis; 3 days retinal pigmentation, body movement, 30 somites; 4 days, body pigmentation; 5 days, fin development; 6 days, swim bladder development; 7 days -2 weeks, growth of embryo; 2 weeks, hatching

is a single site in pCMVTkCAT. Southern blot analysis showed a time course comparable with that observed with the undigested samples (Fig. 3A). The first peak in DNA amount at $24 \mathrm{~h}$ was estimated to contain about 10 times the amount that was injected into the two-cell stage embryo. At day 7, when a second increase of donor DNA is observed, the total amount of plasmid DNA is still approximately fivefold of that injected.

To prove that the increase of the injected DNA is due to replication in the host embryo, DNA was digested with $D p n \mathrm{I}$ which cuts only if DNA is methylated by dam methylase (as is the case for DNA replicated in prokaryotes), and $M b o I$ which cuts only DNA not methylated by dam (as is the case for DNA replicated in eukaryotic cells). While the plasmid DNA preparation used for injection was digested by $D p n I$ (but not by $M b o I)$ the donor DNA from the embryos was exclusively affected by $\mathrm{Mbol}$, as detected by Southern blot hybridization (Fig. 3, bottom).

In summary, the data show that foreign DNA injected into the early embryo of medaka is replicated and that this DNA is maintained for an extended period as intact molecules in an extrachromosomal form.

\section{Expression of foreign $D N A$}

To investigate the suitability of the medaka system for the analysis of transcriptional regulation, the CAT and 
lac $Z$ reporter coding sequences were fused to homologous as well as to heterologous promoter regions and expression was analyzed. While the CAT gene was used to determine the time course of overall expression during ontogenesis of individual fish, the lacZ gene was employed to follow the spatial pattern of expression. Expression of the foreign DNA could be detected in $95 \%$ of the injected embryos tested $(n=500)$. Injection of the control plasmid pBLCAT3 without any functional promoter region resulted in an expression only barely above background level. Injection of plasmid pBLCAT2, containing the Tk promoter alone, revealed a low expression of approximately $1 / 10-1 / 20$ of that obtained with pCMVTkCAT (data not shown).

Three different CAT fusion constructs were used: (i) pCMVTkCAT which contains the cytomegalovirus (CMV) enhancer linked to the promoter of the herpes simplex virus thymidine kinase (Tk) promoter; (ii) phMTCAT which contains the human metallothionein IIa promoter; and (iii) pX47CAT which contains a promoter isolated from the teleost Xiphophorus maculatus. CAT expression determined from single embryos at different times during development revealed that all three constructs display a similar temporal expression pattern, however, with quantitative differences (Fig. 4). As early as $12 \mathrm{~h}$ (early gastrula) after injection of all three plasmids, a low level of CAT expression was seen. Expression increased during the next $12 \mathrm{~h}$ and reached a maximum level $48 \mathrm{~h}$ after injection (early organogenesis). CAT expression remained stable at this high level for up to 3 weeks and decreased thereafter. After 4 weeks, as assayed for pCMVTkCAT, expression generally drops to low levels. However, individual embryos were

Fig. 2. A Slot-blot analysis of DNA extracted from various tissues or parts of the body (columns a, liver and heart; $b$, head; $c$, muscle from the trunk) of 2- to 3-month-old medaka derived from two-cell stage embryos injected with: pX47CAT (lines 1-8), phMTIIaCAT (lines 9-15), pCMVTkCAT (lines 16-22). DNA from uninjected medaka was loaded in slots of line 23 and $50 \mathrm{pg}, 90 \mathrm{pg}$ and $100 \mathrm{pg}$ of pCMVTKCAT was loaded in slots of line 24, a, b, c, respectively; $200 \mathrm{pg}$ plasmid DNA without carrier DNA were loaded in lane 22, column a. DNA per slot loaded was $2.25 \mu \mathrm{g}$ in column a and $6 \mu \mathrm{g}$ in $\mathrm{b}$ and $\mathrm{c}$. For hybridization probe see legend to Fig. 1. B Southern blot analysis of DNA from the head of a 3-month-old medaka fish, which was scored positive in slot-blot analysis. Lane $1,10 \mathrm{pg}$ undigested pX47CAT with $1 \mu \mathrm{g}$ carrier DNA from untreated medaka; lanes $2,3,4 \mu \mathrm{g}$ undigested and $2 \mu \mathrm{g} P s t \mathrm{I}$-digested medaka DNA, respectively. Probe as in Fig. 1. C Southern blot analysis of DNA of a 9-month-old medaka fish, which was injected with pCMVTKCAT at the two-cell stage. DNA was extracted from brain, liver, heart and parts of skin and muscle tissue from the trunk region. Lane $1,100 \mathrm{pg}$ undigested pCMVTkCAT with no additional carrier DNA; lane $2,50 \mathrm{pg} X b a I$-digested pCMVTkCAT without carrier DNA; lane 3, $8 \mu \mathrm{g}$ of DNA analysed after digestion with $X b a I$; lane 4, $10 \mu \mathrm{g}$ DNA analysed untreated. Probe and description of different plasmid conformations as in Fig. 1. The fragment sizes in lane 3 (fragments marked by asterisks) can be explained by the generation of junction fragments due to integration of a single copy of pCMVTkCAT. In the case of integration of plasmid multimers in the usual head-to-tail configuration, an additional internal plasmid monomer fragment would have been expected
A

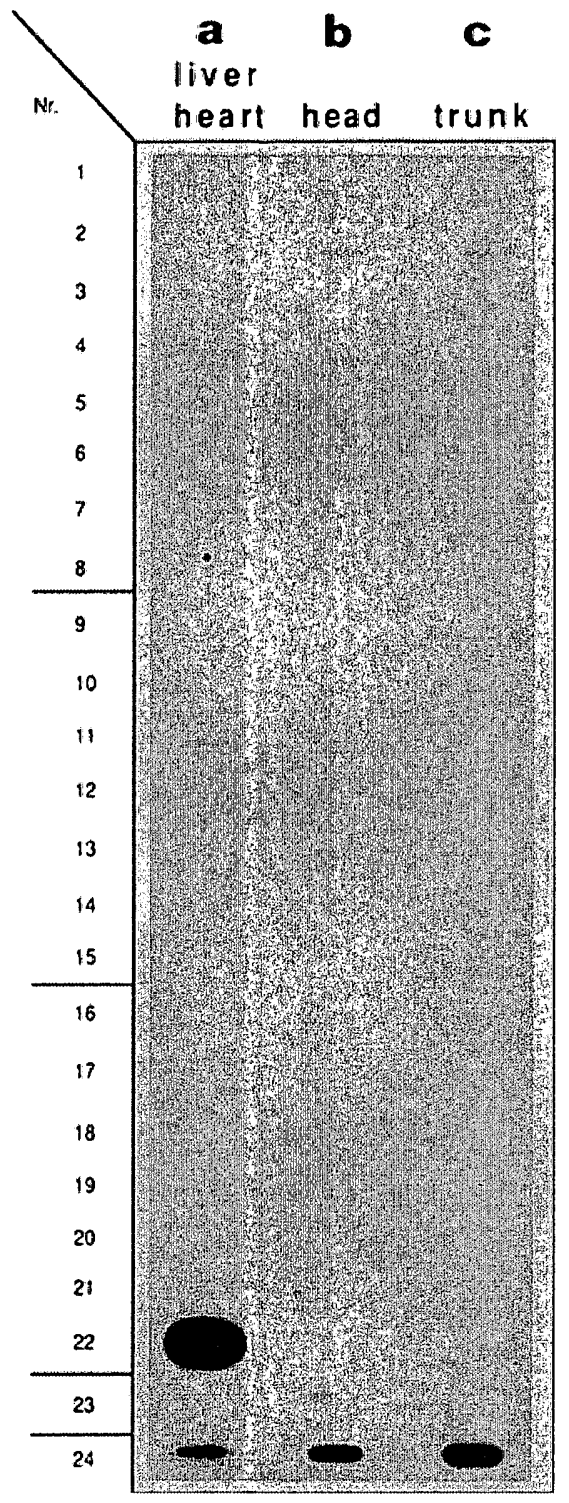

B
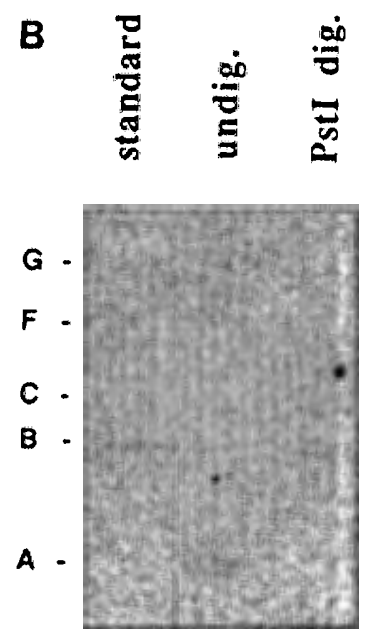

G .

C

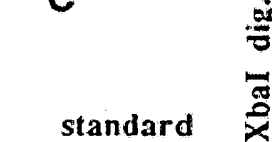

$\frac{4}{\partial-3}$

ํㅠ

$\ddot{\theta}$

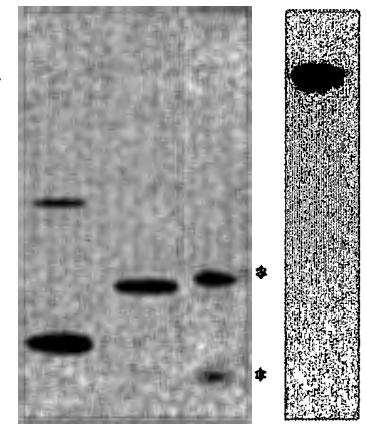

1

3 
A

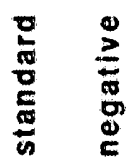

Oh

$0.5 \mathrm{~h}$ ih $6 \mathrm{~h} \quad 1 \mathrm{~d} \quad 2 \mathrm{~d}$

$5.2 \mathrm{~kb}$ -

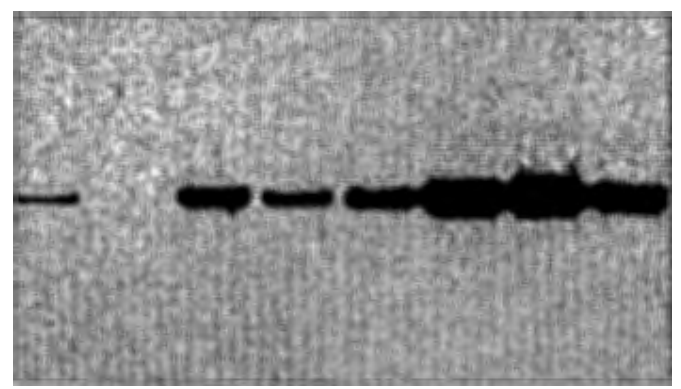

1
B

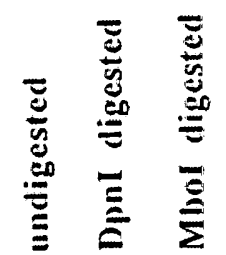

F.

D

Cr

A .

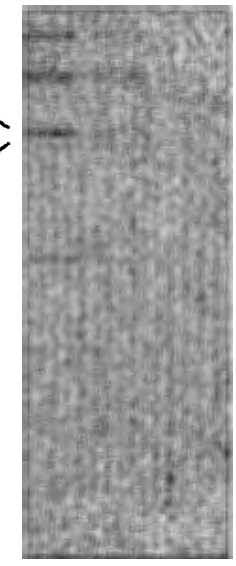

I.
123
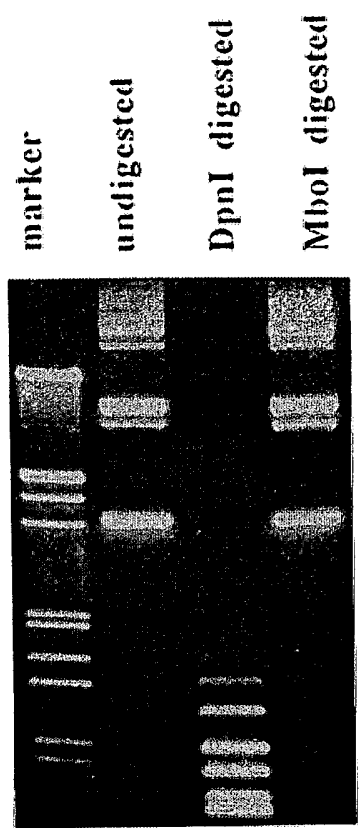

II.

$\begin{array}{llll}4 & 5 & 6 & 7\end{array}$

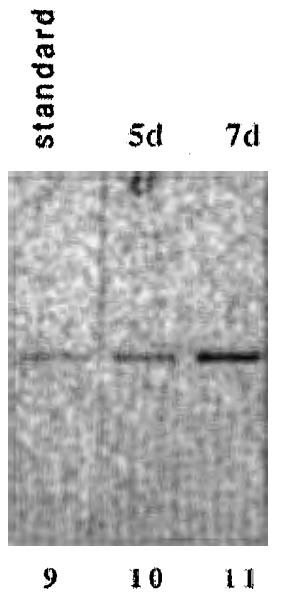

Fig. 3. A Southern blot analysis of aliquots of $X b a \mathrm{I}$ digested DNA from 1.5 embryos of various developmental stages injected at the two-cell stage with plasmid PCMVTKCAT. Each DNA sample contained $250 \mathrm{ng}$ carrier DNA from adult, untreated medaka. Lanes 1, 9, $40 \mathrm{pg} X b a \mathrm{l}$ linearized pCMVTkCAT; lane 2, DNA digest from untreated medaka; lanes 3-11, DNA digest from pCMVTkCAT treated embryos at various times of embryogenesis; for developmental stages see Fig. 1. B I. Southern blot analysis of DNA extracted from six two-day-old embryos, which were injected with pCMVTkCAT at the two-cell stage. Lane 1, one third of the DNA analysed untreated; lane 2, one third analysed after digestion with $D p n l$ and lane 3, one third after digestion with $\mathrm{MboI}$. Probe was used as described in Fig. 1. Lack of hybridizing signals in lane 3 is explained by the small size of fragments generated by MboI digestion of pCMVTkCAT in the region covered by the hybridization probe used. II. Gel electrophoresis of plasmid DNA preparation of pCMVTkCAT. Lane 4, DNA from bacteriophage lambda, EcoRI/HindIII digested; lane 5, $1 \mu \mathrm{g}$ of plasmid DNA undigested; lane 6,1 $\mu \mathrm{g}$ of plasmid DNA DpnI digested; lane 7, $1 \mu \mathrm{g}$ of plasmid DNA MboI digested. A, C, D and F represent the different plasmid conformations as described in Fig. 1 found which still displayed the maximum expression level. Expression values obtained for pCMVTkCAT were generally bigher than those for phMTCAT and pX47CAT. In addition, the values obtained from parallel samples at the same time point were more uniform for pCMVTkCAT but showed marked variation for the other two constructs (Fig. 4).

As phMTCAT, which is expressed in vitro in fish cells only following induction with heavy metal ions (Friedenreich and Schartl 1990), showed high levels of constitutive expression in the embryo, we tested whether a superinduction of this construct is possible in vivo. Plasmid pX47CAT itself contains sequences similar to known metal-response elements and was therefore included in this experiment. Embryos 4 days after injection were incubated with 10,100 and $1000 \mu \mathrm{M} \mathrm{Cd}^{+}$or $\mathrm{Zn}^{2+}$

for $48 \mathrm{~h}\left(\mathrm{LD}_{50}: 1-10 \mathrm{mM}\right)$. Juveniles (3 weeks) were treated for $48 \mathrm{~h}$ with $20 \mu \mathrm{M} \mathrm{Cd}{ }^{+}$or $150 \mu \mathrm{M} \mathrm{Zn}^{2+}$. No enhancement of CAT expression of either constructs was found, as compared to controls. Moreover, a reduction to basal levels was observed in juvenile fish treated with $\mathrm{Zn}^{2+}$.

To study the spatial pattern of expression, two different lac constructs were used: (i) pSV40/2lacZ, which contains the SV40 early promoter; and (ii) $\mathrm{pRSVlacZ}$ containing the Rous sarcoma virus LTR. Staining of embryos after 4 and 8 days revealed large areas of lacpositive cells. In pRSVlac injected embryos, such areas were found in the integument, the myosepta and in the caudal head mesenchyme. However, in 19 out of $40 \mathrm{em}$ bryos injected with pSV40lac, staining was observed exclusively in neural tissues (for example see Fig. 5C). 

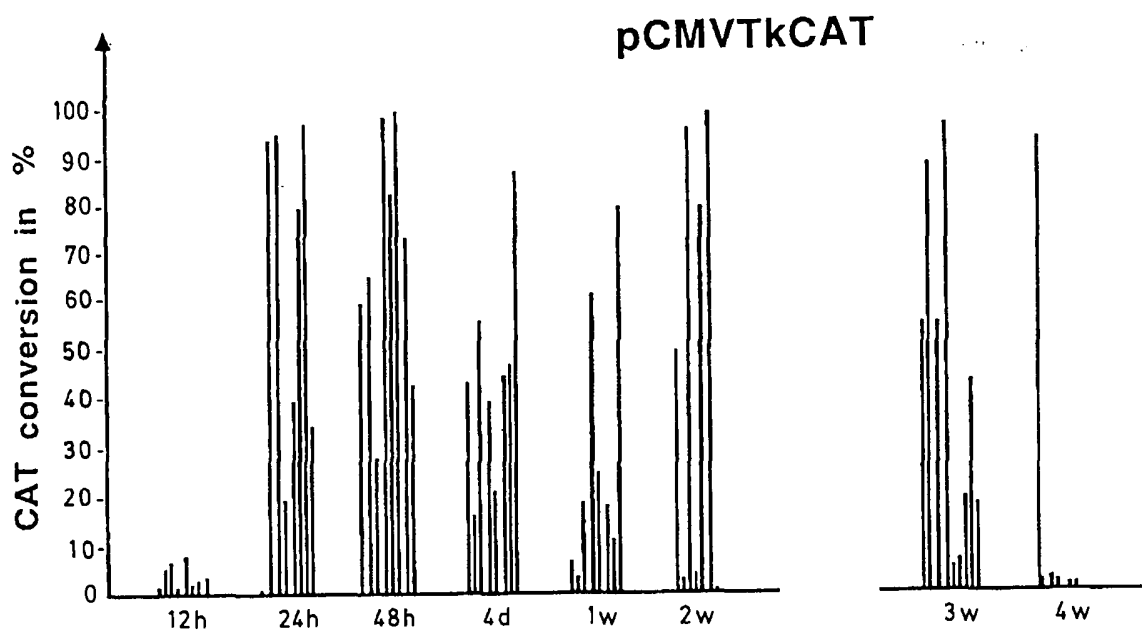

time after injection
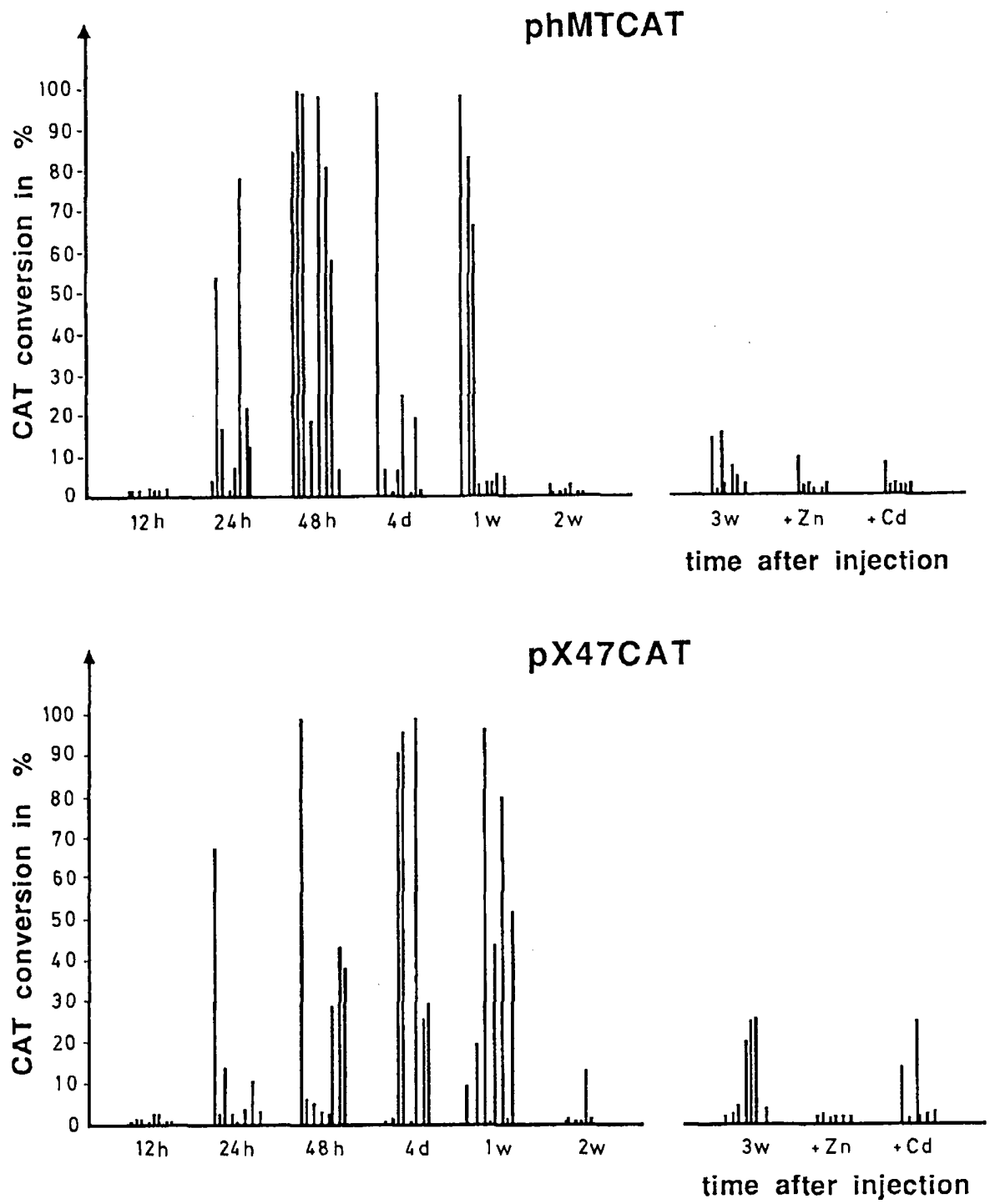

Fig. 4. CAT expression pattern during embryonic and larval medaka development as result of injection of various enhancer-promoter driven CAT genes. One line represents one individual embryo or hatchling. Three-week-old hatchlings injected with phMTCAT and pX47CAT were additionally treated with $\mathrm{ZnCl}_{2}$ or $\mathrm{CdCl}_{2}$. CAT conversion values for non-injected control embryos ranged between 0.3 and $1.3 \%$ 

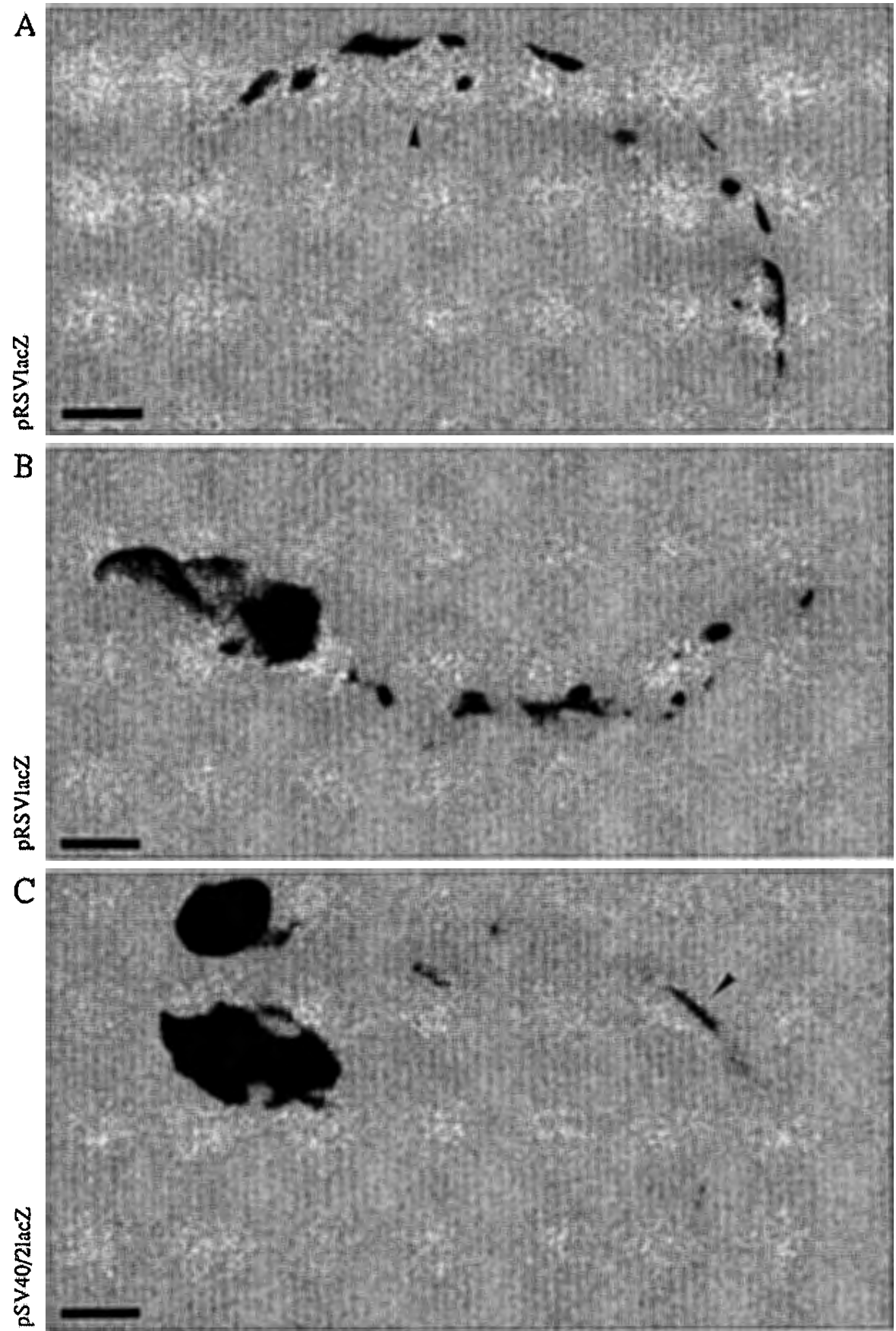

Fig. 5A-C. LacZ expression in 4-dayold embryos injected with pRSVlacZ $(A, B)$ and in a 8-day-old embryo injected with pSV40/2lacZ (C). Arrows indicate the background signal presumably due to endogenous $\beta$-galactosidase(s) present in the intestine in (A) and (C). The intestine has been completely removed in (B). (bar $=0.2 \mathrm{~mm}$ )

LacZ expression was found in 44 of 116 embryos tested. None of the lacZ-positive embryos showed expression in all cells of a given tissue; only a limited fraction of the total cell population of the whole embryo (max. up to $20 \%$ ) was lac-positive. It should be noted that the assay for lacZ expression by $\mathrm{X}$-gal staining of embryos in our studies is not as sensitive as monitoring CAT activity. Whereas we found CAT activity in $95 \%$ of the 500 embryos tested, the rate of embryos stained with $\mathrm{X}$-gal was only $38 \%$. In contrast, measurement of $\beta$ galactosidase activity in extracts of lacZ-injected em- broys by incubation wtih ONPG (o-nitrophenyl- $\beta$-D-galactopyranoside) revealed expression in more than $90 \%$ of the injected embryos (data not shown).

\section{Discussion}

Our data on the expression of reporter genes regulated by fish and heterologous transcriptional control regions following microinjection into the two-cell stage embryo of a teleost fish, the Japanese medaka ( $O$. latipes), indicate that this in vivo system offers a powerful approach 
for studies of gene regulation in embryonic and larval fish development. In agreement with previous data (Ozato et al. 1986; Chong and Vielkind 1989), we were able to show that these fish are easy to mâintain and microinject.

Following injection of up to $25 \mathrm{pg}$ of foreign DNA, which is more than 10 times as much as the DNA content of a diploid medaka cell, into the cytoplasm of the two-cell stage embryo, we observed conformational changes of the donor DNA. These included not only supercoiling and linearization of the circular molecules but also the formation of both covalently (concatemers) or non-covalently (concatenates) linked multimers. Similar observations have been made in higher vertebrates after transfer of circular plasmid DNA into cells in vitro or in vivo (Folger et al. 1982; Brinster et al. 1985; Marini et al. 1988) and in previous studies in fish embryos (Chong and Vielkind 1989). However, in sea urchins it has been shown that injected circular plasmid DNA is neither concatemerized nor replicated (McMahon et al. 1985). Only linear plasmid molecules were found to be multimerized in random head-to-head and head-to-tail orientations due to ligation of linear termini. In Xenopus and mammalian cells, on the other hand, the formation of linear, exclusively head-to-tail multimers after injection of circular DNA has been previously shown (Rusconi and Schaffner 1981; Folger et al. 1982; Etkin et al. 1984). A homologous recombination mechanism was postulated that, in the case of Xenopus, is also thought to be responsible for the formation of head-to-tail concatemers after injection of linearized plasmid DNA (Marini et al. 1988). In our studies using Southern blot analysis we could not detect formation of head-to-head or tail-to-tail concatemers because digestion of DNA extracted from injected embryos with an enzyme that cuts the introduced plasmid once showed no additional bands (Fig. 3, top). This indicates that the concatemers shown in Fig. 1 consist mainly of head-to-tail plasmid multimers, supporting a homologous recombination mechanism for their formation also. Over the period analyzed, the conformational changes result in a relative enrichment for hmw forms, which are generally considered to be a prerequisite for successful integration of donor DNA into the host genome (Brinster et al. 1985; Etkin and Pearman 1987; Etkin et al. 1984). The signal comigrating with the hmw DNA of the recipient is already visible $6 \mathrm{~h}$ after injection at the early blastula stage (see also Chong and Vielkind 1989), in contrast to findings in Xenopus, where such signals become detectable no earlier than late blastula stage (Etkin et al. 1984). Although the extended presence of foreign DNA tempts us to suggest that integration might have occurred in a few cases - as shown in one single 9-month-old recipient fish - this possibility was not investigated in detail because our main objective was directed to establishing a transient expression system. However, it should be noted that in a 3-month-old fish we still detected extrachromosomal supercoiled plasmid DNA in addition to a faint signal in the hmw DNA.

Surprisingly, in contrast to all findings in mammalian DNA transfer systems (Brinster et al. 1985), we obtained an increase in the amount of extrachromosomally persisting DNA. Although the constructs analyzed did not contain any specific sequences which are known or proposed to support DNA replication in eukaryotes (Heintz and Hamlin 1982; Burhans et al. 1986), this increase can only be explained by replication of the foreign DNA in the embryo. In Xenopus, extrachromosomal replication of the introduced plasmids has also been shown (Etkin et al. 1984, 1987; Marini et al. 1988, 1989). Replication was independent of specific sequences, but dependent on number and size of injected plasmid molecules. However, replication of foreign DNA was found only up to gastrulation and occurred mainly in hmw concatemers (Rusconi and Schaffner 1981; Etkin et al. 1984; Marini et al. 1988). In older embryos only limited amounts of foreign DNA persisted due to degradation. Studies using the zebrafish and the medaka (Stuart et al. 1988; Chong and Vielkind 1989) also obtained evidence for an increase of the injected DNA during very early development. We could show, using the $M b o l / D p n I$ digestion, that this increase is actually due to DNA replication in the recipient. Replication was observed for a prolonged period of time and was also found to include plasmid monomers. Even 3 days after injection, when organogenesis is complete, we detected large amounts of foreign DNA. Interestingly, we found a second peak in the amount of DNA due to replication 7 days after injection. This could be due to an increased rate of replication of DNA because of the rapid growth of the embryo at this time.

In our studies, DNA was always injected into the cytoplasm, however, it is possible that significant amounts could have ended up in the nucleus, undergoing replication there. Alternatively, replication might also occur outside the nucleus. Following injection of phage lambda DNA, the formation of so called nucleus-like particles from the foreign DNA has been reported in Xenopus (Forbes et al. 1983). It was also shown in Xenopus that in later stages the foreign DNA is mainly localized in the nucleus (Etkin and Pearman 1987). It was suggested that the nucleus-like particles may randomly fuse with the nucleus in the following developmental stages. Such processes could be responsible (i) for a mosaic distribution of foreign DNA to daughter cells, and (ii) for replication and transcription of the foreign DNA by host nuclear enzymes. Additionally, it has been suggested that maternal enzymes are responsible for the conformational changes in and replication of the foreign DNA in the very early embryo (Zierler et al. 1985; Marini et al. 1988). This might not account for the findings in the medaka system, because here replication occurs also in later stages.

We could show that the foreign DNA is expressed and that this expression is dependent on the promoter used. The CMVTk promoter construct was found to result in the highest and most persistent expression, which is consistent with findings in vitro in fish cells (Friedenreich and Schartl 1990) and in higher vertebrate cells (Boshart et al. 1985). The hMT promoter, in contrast to the in vitro data (Friedenreich and Schartl 1990), was constitutively active during embryogenesis and was 
not inducible in post-hatching fish. In transgenic mice, constitutive activity of MT promoters was also observed in early embryonic stages, possibly due to the presence of embryo factors that regulate the activity of the promoter. However, the MT promoters were inducible by heavy metal ions in later stages in mice (Palmiter and Brinster 1986). The X47 promoter, which is the only fish promoter sequence available to date, showed the same features in injected embryos as after transfection into several cell lines (Friedenreich and Schartl 1990). To the best of our knowledge this is the first report of expression mediated by a fish promoter sequence in an in vivo fish gene transfer system.

Using the lac $Z$ gene as a reporter, we were able to determine different spatial patterns of expression depending on the regulatory regions used. With the SV 40 early promoter we found expression mainly in developing neural organs of the fish. This is consistent with findings in transgenic mice (Brinster et al. 1984). The RSV promoter led to a preferential expression in epidermal derivatives and epithelial tissues derived from the mesoderm. The latter findings is in agreement with results in transgenic mice (Overbeek et al. 1986) while epidermal expression directed by the RSV-LTR has not been reported so far in in vivo gene transfer experiments.

As we could show no junction fragments indicative of integration foreign DNA in up to 1-week-old embryos using Southern blot analysis (Fig. 3, top) it is clear that expression of reporter genes, as shown in $95 \%$ of the embryos tested, has to derive from non-integrated, extrachromosomal plasmid copies. In total we found integration of foreign DNA in only 1 out of 25 tested adult $\mathrm{F}_{0}\left(\mathrm{G}_{0}\right)$ fish, injected at the two-cell stage. The observation that in almost all cases the expression of reporter genes drops to zero after 2-4 weeks, together with the observed low integration rate, confirms the fact that the introduced DNA is mainly expressed transiently in an extrachromosomal manner.

The mosaic character of the spatial expression pattern may be due to the rapid cell divisions and pronounced cell migration in the early fish embryo. As a result, the injected DNA is unevenly distributed and therefore may be retained only in distinct cell lineages. Using even higher amounts of donor DNA for injection and microinjecting into the oocyte prior to artificial insemination could help to overcome this problem. The patchy appearance of the lacZ-positive organs or tissues indicates that determination of organ and/or tissue specificity in the developing embryo occurs at a later stage. This supports findings from classical embryology using the zebrafish, which indicated considerable indeterminancy in the embryonic lineage and no lineage restrictions on embryonic cell fate before the gastrula stage (Kimmel and Warga 1988). It also shows that the descendants of different blastomeres normally intermix extensively prior to formation of embryonic organs, as has been deduced from genetic and mutagenesis studies (Streisinger et al. 1989).

Gene expression studies in vivo using stable transgenic lines are of considerable importance for experimental cancer research. The major criticism of the usefulness of such models is that stable transgenics cannot mimic spontaneous tumorigenesis in one very important aspect.
Instead of small isolated nests of activated oncogenebearing cells that interact with normal neighbour cells, the transgenic animals have tissues in which virtually all cells express the activated oncogene (Weinberg 1989). The mosaic pattern of expression which is obtained in the medaka embryo does not have this drawback. Moreover, it mimics the actual situation of an initiated cell or cell clone in normal surroundings.

Recently, fish embryology has attracted considerable attention and is expected to offer a promising system for vertebrate developmental biology in the future (Marcey and Nüsslein-Volhard 1986). The transient expression system of the medaka additionally allows the analysis of developmental processes at the molecular level with respect to differential gene expression. Future studies will show whether the transient expression system described here can also be used for the functional expression of structural genes and, if phenotypic effects are obtained, whether it will allow analysis of the function of the respective genes.

Acknowledgements. We thank R. Renkawitz, Martinsried, for kindly providing the plasmids pCMVTkCAT and pRSVlacZ and $\mathrm{H}$. Friedenreich, Martinsried, for phMTIIaCAT and pX47CAT. We gratefully acknowledge the technical assistance of B. Schmidt. This work was supported by a grant from the G.I.F. (Nr. I-18-127.3/87) and the Bundesministerium für Forschung und Technologie through Schwerpunkt "Grundlagen und Anwendungen der Gentechnologie" (No. 26) to MS and by grants from NIH (USA) and MRC (Canada) to JRV. JRV is a scholar of the Medical Research Council of Canada.

\section{References}

Agellon LB, Chen TT (1986) Rainbow trout growth hormone: Molecular cloning of cDNA and expression in Escherichia coli. DNA 5:463-471

Bonham K, Zafarullah M, Gedamu L (1987) The rainbow trout metallothioneins: Molecular cloning and characterization of two distinct cDNA sequences. DNA 6:519-528

Boshart M, Weber F, Jahn G, Dorsch-Häsler K, Fleckenstein B, Schaffner W (1985) A very strong enhancer is located upstream of an immediate early gene of human cytomegalovirus. Cell $41: 521-530$

Brinster RL, Chen HY, Messing A, van Dyke T, Levine AJ, Palmiter RD (1984) Transgenic mice harboring SV40 T antigen genes develop characteristic brain tumors. Cell 37:367-379

Brinster RL, Chen HY, Trumbauer ME, Yagle MK, Palmiter RD (1985) Factors affecting the efficiency of introducing foreign DNA into mice by microinjecting eggs. Proc Natl Acad Sci USA 82:4438-4442

Burhans WC, Selegue JE, Heintz NH (1986) Isolation of the origin of replication associated with the amplified chinese hamster dihydrofolate reductase domain. Proc Natl Acad Sci USA 83:7790-7794

Chong SSC, Vielkind JR (1989) Expression and fate of CAT reporter genes microinjected into fertilized medaka (Oryzias latipes) eggs in the form of plasmid DNA, recombinant phage particles and its DNA. Theor Appl Genet 78:369-380

Eiken HG, Njolstrad PR, Molven A, Fjose A (1987) A zebrafish homeobox-containig gene with embryonic transcription. Biochem Biophys Res Commun 149:1165-1171

Etkin LD, Balcells S (1985) Transformed Xenopus embryos as a transient expression sytem to analyze gene expression at the midblastula transition. Dev Biol 108:173-178

Etkin LD, Pearman B (1987) Distribution, expression and germ line transmission of exogenous DNA sequences following microinjection into Xenopus laevis eggs. Development 99:15-23

Etkin LD, Pearman B, Roberts M, Bektesh SL (1984) Replication, 
integration and expression of exogenous DNA injected into fertilized eggs of Xenopus laevis. Differentiation 26:194-202

Etkin LD, Pearman B, Ansah-Yiadom R (1987) Replication of injected DNA templates. Exp Cell Res 169:468-477

Feinberg AP, Vogelstein B (1983) A technique for radiolabeling DNA restriction endonuclease fragments to high specific activity. Anal Biochem 132:6-13

Fire A (1986) Integrative transformation of Caenorhabditis elegans. EMBO J 5:2673-2680

Fjose A, Molven A, Eiken HG (1988) Molecular cloning and characterization of homeobox-containing genes from atlantic salmon. Gene 62:141-152

Flytzanis CN, McMahon AP, Hough-Evans BR, Katula KS, Britten RJ, Davidson EH (1985) Persistence and integration of cloned DNA in postembryonic sea urchins. Dev Biol 108:431442

Folger KR, Wong EA, Wahl G, Capecchi MR (1982) Patterns of integration of DNA microinjected into cultured mammalian cells : Evidence for homologous recombination between injected plasmid DNA molecules. Mol Cell Biol 2:1372-1387

Forbes DJ, Kirschner MW, Newport JW (1983) Spontaneous formation of nucleus-like structures around bacteriophages. DNA microinjected into Xenopus eggs. Cell 34:13-23

Friedenreich H, Schartl M (1990) Transient expression directed by homologous and heterologous promoter and enhancer sequences in fish cells. Nucleic Acids Res 18:3299-3305

Gonzales-Villasenor LI, Zhang P, Chen TT, Powers DA (1988) Molecular cloning and sequencing of coho salmon growth hormone cDNA. Gene 65:239-246

Gorman CM, Merlinao GT, Willingham MC, Pastan I, Howard BH (1982a) The Rous sarcoma virus long terminal repeat is a strong promoter when introduced into a variety of eukaryotic cells by DNA-mediated transfection. Proc Natl Acad Sci USA 79:6777-6781

Gorman CM, Moffat L, Howard B (1982 b) Recombinant genomes which express chloramphenicol acetyl transferase in mammalian cells. Mol Cell Biol 2:1044-1051

Guyomard R, Chourrout D, Leroux C, Houdebine LM, Pourrain $F(1989)$ Integration and germ line transmission of foreign genes microinjected into fertilized trout eggs. Biochimie 71:857-863

Hannig G, Ottilie S, Schartl M (1991) Conservation of structure and function of the c-yes and fyn genes in lower vertebrates. Oncogene 6: (in press)

Harland RM, Weintraub H, McKnight SL (1983) Transcription of DNA injected into Xenopus oocytes is influenced by template topology. Nature 302:38-43

Heintz NH, Hamlin JL (1982) An amplified chromosomal sequence that includes the gene for dihydrofolate reductase initiates replication within specific restriction fragments. Proc Natl Acad Sci USA 79:4083-4087

Holmes DS, Quigley M (1981) A rapid boiling method for the preparation of bacterial plasmids. Anal Biochem 114:193-197

Jaenisch R (1988) Transgenic animals. Science 240:1468-1474

Karin M, Richards RI (1982) Human metallothionein genes - primary structure of the metallothionein-II gene and a related processed gene. Nature 299:797-802

Kimmel CB, Warga RM (1988) Cell lineage and developmental potential of cells in the zebrafish embryo. Trends Genet 4:68-74

Kirchen RV, West WR (1976) The Japanese medaka - its care and development. Carolina Biological Supply Company, Burlington, North Carolina

Krone PH, Heikkila JJ (1989) Expression of microinjected hsp 70/CAT and hsp 30/CAT chimeric genes in developing Xenopus laevis embryos. Development 106:271-281

Luckow B, Schütz G (1987) CAT constructions with multiple unique restriction sites for the functional analysis of eukaryotic promoters and regulatory elements. Nucleic Acids Res 15:5490

Maclean N, Penman D, Zhu Z (1987) Introduction of novel genes into fish. Biotechnology 5:257-261

Marcey D, Nüsslein-Volhard C (1986) Embryology goes fishing. Nature 321:380-381

Marini NJ, Etkin LD, Benbow RM (1988) Persistence and replica- tion of plasmid DNA microinjected into early embryos of Xenopus laeyis. Dev Biol 127:421-434

Marini NJ, Hiriyanna KT, Benbow RM (1989) Differential replication of circular DNA molecules co-injected into early Xenopus laevis embryos. Nucleic Acids Res 17:5793-5808

Martin P, Martin A, Osmani A, Sofer W (1986) A transient expression assay for tissue-specific gene expression of alcohol dehydrogenase in Drosophila. Dev Biol 117:574-580

McMahon AP, Moon RT (1989) Ectopic expression of the protooncogene int -1 in Xenopus embryos leads to duplication of the embryonic axis. Cell 58:1075-1084

McMahon AP, Flytzanis CN, Houg-Evans BR, Katula KS, Britten RJ, Davidson EH (1985) Introduction of cloned DNA into sea urchin egg cytoplasm: replication and persistence during embryogenesis. Dev Biol 108:420-430

Nemoto N, Kodama K, Tazawa A, Masahito P, Ishikawa T (1986) Extensive sequence homology of the goldfish ras gene to mammalian ras genes. Differentiation 32:17-23

Njølstad PR, Molven A, Apold J, Fjose A (1990) The zebrafish homeobox gene hox-2.2: transcription unit, potential regulatory regions and in situ localization of transcripts. EMBO J 9:515524

Olson MV, Loughney K, Hall BD (1979) Identification of the yeast DNA sequences that correspond to specific tyrosine-inserting nonsense suppressor loci. J Mol Biol 132:387-410

Overbeek PA, Lai SP, Van Quill KR, Westphal H (1986) Tissuespecific expression in transgenic mice of a fused gene containing RSV terminal sequences. Science $231: 1574-1577$

Ozato $\mathrm{K}$, Kondoh $\mathrm{H}$, Inohara $\mathrm{H}$, Iwamatsu $\mathrm{T}$, Wakamatsu $\mathrm{Y}$, Okada TS (1986) Production of transgenic fish: Introduction and expression of chicken $\delta$-crystallin gene in medaka embryos. Cell Differ 19:237-244

Ozato K, Inoue K, Wakamatsu Y (1989) Transgenic fish: Biological and technical problems. Zool Sci 6:445-457

Palmiter RD, Brinster RL (1986) Germ line transformation of mice. Annu Rev Genet 20:465-499

Powers DA (1989) Fish as model systems. Science 246:352-358

Reed KC, Mann DA (1985) Rapid transfer of DNA from agarose gels to nylon membranes. Nucleic Acids Res 13:7207-7214

Rubin GM, Spradling AC (1982) Genetic transformation of Drosophila with transposable element vectors. Science 218:348-353

Rugh RCh (1962) Experimental Embryology Techniques and Procedures, 3rd edn. Burgess Publishing Co, Minneapolis

Rusconi S, Schaffner W (1981) Transformation of frog embryos with a rabbit $\beta$-globin gene. Proc Natl Acad Sci USA 78:50515055

Schartl M, Wittbrodt J, Mäueler W, Raulf F, Adam A, Hannig G, Telling A, Storch F, Andexinger S, Robertson SM (1991) Oncogenes and melanoma formation in Xiphophorus. In: Schröder JH, Schartl M (eds) New Trends in Ichthyology. Parey Verlag, Munich, in press

Sekine S, Mizukami T, Nishi T, Kuwana Y, Saito A, Sato M, Itoh S, Kawauchi $H$ (1985) Cloning and expression of cDNA for salmon growth hormone in Escherichia coli. Proc Natl Acad Sci USA 82:4306-4310

Steller H, Pirrotta V (1984) Regulated expression of genes injected into early Drosophila embryos. EMBO J 3:165-173

Streisinger G, Walker C, Dower N, Knauber D, Singer F (1981) Production of clones of homozygous diploid zebrafish (Brachydanio rerio). Nature 291:293-296

Streisinger G, Coale F, Taggart C, Walker C, Grunwald DJ (1989) Clonal origins of cells in the pigmented retina of the zebrafish eye. Dev Biol 131:60-69

Stuart GW, McMurray JV, Westerfield M (1988) Replication, integration and stable germ line transmission of foreign sequences injected into early zebrafish embryos. Development 103:403412

Surani MA, Reik W, Allen ND (1988) Transgenes as molecular probes for genomic imprinting. Trends Genet $4: 59-62$

Van Beneden RJ, Watson DK, Chen TT, Lautenberger JA, Papas TS (1986) Cellular myc (c-myc) in fish (rainbow trout): Its relationship to other vertebrate myc genes and to the transforming 
genes of the MC29 family of viruses. Proc Natl Acad Sci USA 83:3698-3702

Vielkind JR, Kallmann KD, Morizot DC (1989) Genetics of melanomas in Xiphophorus fishes. J Aquatic Animal Health 1:69-77

Vielkind JR,. Chong SSC, Stuart GW, Sadaghiani B (1990) Transgenic medaka and zebrafish systems: Transient and inherited expression of a recombinant CAT reporter gene microinjected into fertilized eggs. In: Schröder JH, Schartl M (eds) New Trends in Ichthyology. Parey Verlag, Munich, in press

Weinberg RA (1989) Oncogenes, Antioncogenes, and the molecular bases of multistep carcinogenesis. Cancer Res 49:3713-3721

Weintraub H, Cheng PF, Conrad K (1986) Expression of transfected DNA depends on DNA topology. Cell 46:115-122
Wittbrodt J, Adam D, Malitscheck B, Mäueler W, Raulf F, Telling A, Robertson SM, Schartl M (1989) Novel putative receptor tyrosine kinase encoded by the melanoma-inducing Tu locus in Xiphophorus. Nature 341:415-421

Yamamoto T (1961) Physiology of fertilization in fish eggs. Int Rev Cytol 12:361-405

Zierler MK, Marini NJ, Stowers DJ, Benbow RM (1985) Stockpiling of DNA polymerases during oogenesis and embryogenesis in the frog, Xenopus laevis. J Biol Chem 260:974-981

Communicated by J. Campos-Ortega 